\title{
Feeling about living arrangements and associated health outcomes among older adults in India: a cross-sectional study
}

\author{
Shobhit Srivastava ${ }^{1} \mathbb{D}$, Subhojit Shaw ${ }^{1} \mathbb{D}$, Himanshu Chaurasia ${ }^{2}$, Naina Purkayastha ${ }^{3}$ and T. Muhammad ${ }^{1 *}$ (D)
}

\begin{abstract}
Introduction: Advancement in the field of gerontology has been concerned with the well-being of older adults in a family setup that is associated with caregiving and support. While family life and well-being are defined by emotion, caregiving, and support activities, dissatisfaction/discontent with living arrangements is a public health concern, which is increasing with a rise in the proportion of the older population in the country. The study examines the association of dissatisfaction with living arrangements with health outcomes among older men and women in India.

Methods: The present research used data from the 'Building a Knowledge Base on Population Aging in India'. The effective sample size for the analysis was 9181 older adults. Descriptive statistics and bivariate analysis were performed to present the preliminary estimates. For finding the association between various health outcomes over explanatory variables, binary logistic regression model was used separately for men and women.

Results: About $22.8 \%$ of men and $30.8 \%$ of women who were living alone were dissatisfied with their present living arrangement. It was revealed that both men and women who were dissatisfied with their present living arrangements had significantly higher odds of experiencing poor self-rated health [OR:4.45, $3.25 \sim 6.09$ and OR:3.32, 2.54 4.34], low psychological health [OR: 2.15, $1.61 \sim 2.86$ and OR: 1.99, $1.57 \sim 2.53$ ], low subjective well-being [OR: 3.37, $2.54 \sim 4.45$ and OR: 3.03, $2.36 \sim 3.38$ ], low ADL [OR: 1.77, $1.2 \sim 2.62$ and OR: 1.59, 1.17 2.18, low IADL] [OR: 1.32, $1.03 \sim 1.69$ and OR: 1.57, $1.24 \sim 1.98$ ] and low cognitive ability [OR: 1.26, $0.98 \sim 1.61$ and OR:1.44, $1.13 \sim 1.82$ ] in comparison to their counterpart from men and women respectively.

Conclusion: It is found that dissatisfaction with the living arrangement of older men and women is negatively associated with major health outcomes. Hence, appropriate policies and programs must be developed to promote increased family care and support and an improved residential environment that would create a feeling of comfort and happiness among older individuals.
\end{abstract}

Keywords: Dissatisfaction, Living arrangement, Health, Older adults, India

\footnotetext{
* Correspondence: muhammad@iips.net

${ }^{1}$ International Institute for Population Sciences, Mumbai, Maharashtra 400088, India

Full list of author information is available at the end of the article
}

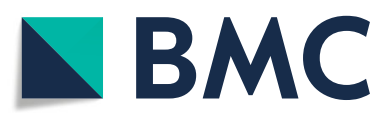

(- The Author(s). 2021 Open Access This article is licensed under a Creative Commons Attribution 4.0 International License, which permits use, sharing, adaptation, distribution and reproduction in any medium or format, as long as you give appropriate credit to the original author(s) and the source, provide a link to the Creative Commons licence, and indicate if changes were made. The images or other third party material in this article are included in the article's Creative Commons licence, unless indicated otherwise in a credit line to the material. If material is not included in the article's Creative Commons licence and your intended use is not permitted by statutory regulation or exceeds the permitted use, you will need to obtain permission directly from the copyright holder. To view a copy of this licence, visit http://creativecommons.org/licenses/by/4.0/ The Creative Commons Public Domain Dedication waiver (http://creativecommons.org/publicdomain/zero/1.0/) applies to the data made available in this article, unless otherwise stated in a credit line to the data. 


\section{Introduction}

Since aging is usually associated with declining economic resources, decreasing cognitive ability, deteriorating physical health, and weakening social support [1], several studies have attempted to identify various correlates that influence different health outcomes among older adults. An important link between living arrangements and older adults' health has been established suggesting that the living setup can affect levels and types of physical and psychological support older adults receive $[2,3]$. However, the complexities of well-being at later phases may vary by the number of younger family members, differing emotional attachments, and caregiving [4, 5]. Further, researchers have found a positive association of family support with the self-rated health of older adults [6, 7]. A recent study also found that older adults who prefer a shared living arrangement among their adult children tend to report negative health outcomes [8]. Studies have also investigated the effects of the residential environment on the subjective well-being of older adults [9-12].

While the decline in co-residence with children reduced the familial support for older adults, as evidence suggests, it eventually led to increased psychological illnesses in later years of their lives [13-15]. Similarly, a substantive body of literature exists regarding the mediating role of familial support system between living arrangements and health of older people [16-19]. Kaufman, (2018) has found evidence of keeping a successful intimate partner that leads to improvement of all dimensional health [20]. In this regard, the enhanced familial ties have been perceived as an alternative for preventing negative health behaviors [21].

\section{Feeling about living arrangement and health status}

Adequate care and support from the family, higher levels of satisfaction with living environments, and staying in their own home plays a crucial role in achieving successful aging [22, 23]. A voluminous body of literature exists regarding the factors related to satisfaction with single/ co-residential living arrangements of older people [19, $24,25]$. Study shows that older persons who moved to a co-residential arrangement felt uncomfortable in the new environment due to their new status of having to depend on others for their day-to-day care needs [26]. Recent studies in India found that older people expressed satisfaction and a strong desire for remaining in their own homes and reported a sense of independence and autonomy in such living settings [3, 27].

Thus, advancement in the field of gerontology has been concerned with the feeling about the family setup that is associated with caregiving and support and the well-being of older adults. However, in India, studies that focused on feelings about living arrangements among older adults and their association with the health outcomes is scant. Moreover, since it is not the same to be ill (an objective condition) as it is to suffer from an illness (a subjective condition), objective health indicators cannot fully capture the richness of how families react to illness to reduce its impact on the wellbeing of the family $[28,29]$. While assessing the health status of older adults, subjective wellbeing is also considered to be a key component [21]. Along with that, ADL and IADL are important tools to measure the overall health and wellbeing [30].

The purpose of the present study is to empirically examine the dissatisfaction with living arrangements and health outcomes among older men and women in India. Here, we hypothesize that the satisfaction with living arrangement is positively associated with better health outcomes among older adults.

\section{Methods \\ Data}

The present research used data from Building a Knowledge Base on Population Aging in India (BKPAI) which was National level survey and was conducted in 2011, across seven states of India. The survey was sponsored by Institute for social and economic change (ISEC), Tata Institute for social sciences (TISS), Institute for economic growth (IEG), and (United Nations Population Fund) UNFPA, New Delhi. The survey gathered information on various socio-economic and health aspects of aging among households of those aged 60 years and above. The data from seven states were collected which represents the various regions of India namely, North India, South India, Western India, and Eastern India [31].

Being the survey of the older adults, the sample size was equally split between urban and rural areas, irrespective of the proportion of the urban and rural population. Eighty Primary Sampling Units (PSU) (villages or urban wards) - 40 urban and an equal number of rural - with 16 households per Primary Sampling Unit (PSU) having an older person were covered in the survey [31]. BKPAI collected information from 9850 older adults aged 60 years and above who were interviewed from 8329 households [31]. The sample included for the analysis after performing all pre-analysis procedures like dropping the missing data (583) and outliers (86 cases) was 9181 older adults (Fig. 1).

\section{Variable descriptions Outcomes variables}

The study analyzed six outcomes, collected through various tools that were previously used in the Indian context to categorize them in both continuous and binary forms. 
Total participants in BKPAI: 10,604 olde adults aged 60 years and above

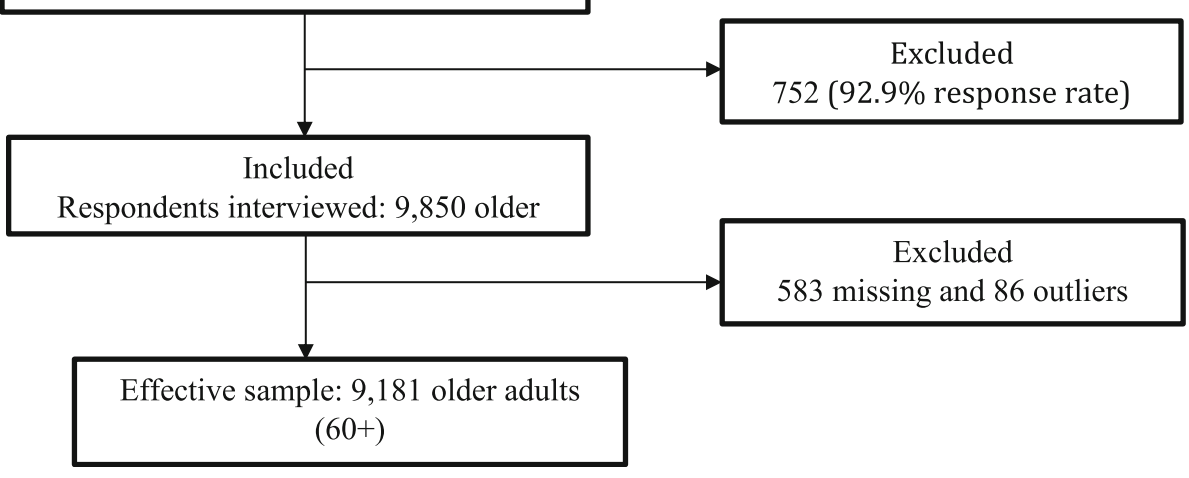

Fig. 1 Sample selection for the present study

The six outcome variables were self-rated health, psychological health, subjective well-being (SWB), ability to do activities of daily living (ADL), ability to do instrumental activities of daily living (IADL), and cognitive ability.

The outcome variables were used in two forms. Firstly in the form of the index which was used to calculate mean by background characteristics and secondly in the form of the binary function to run binary logistic regression analysis. Self-rated health was having a scale of 1 to 5 "poor to excellent" and was categorized as 0 "good" (representing good, very good, and excellent) and 1 "poor" (representing poor or fair) [32]. Psychological health was having a scale of 0 to 12 based on experiencing stressful symptoms and was recoded as 0 "high" (representing 6+ scores) and 1 "low" (representing score 5 and less) [33, 34] (Cronbach Alpha: 0.90). Subjective wellbeing [8] was having a scale of 0 to 9 and was categorized as 0 "high" experiencing better experience (representing 6+ scores) and 1 "low" experiencing negative experience (representing score 5 and less) [35] (Cronbach Alpha: 0.89).

Ability to do activities of daily living was having a scale of 0 to 6 wherein it represents higher the score higher the independence. A score of was categorized as 0 "high" which represents full independence and 5 and less was categorized as 1 "low" which represents not fully independent to do activities of daily living (Cronbach Alpha: 0.93) [36]. The ability to do instrumental activities of daily living was having a scale of 0 to 8 representing higher the score higher the independence. A score of 6+ was categorized as 0 "high" representing high IADL and a score of 5 and less was recoded as 1 "low" representing low IADL $[37,38]$. Cognitive ability was measured by the number of words recalled. To measure cognitive ability a scale of 0 to 10 was prepared representing higher the score better the cognitive ability. Five or more words were recoded as 0 "high" representing better cognitive ability and a score of four or less was recoded as 1 "low" representing low cognitive ability [39, 40]. The cut-offs for the outcome variables are based on the literature available and the (Additional file 1) contains all the questions and their recoding.

\section{Explanatory variables}

Feeling about the present living arrangement was assessed through the question "How do you feel about your present living arrangement" and was categorized as 0 "satisfactory" which includes comfortable and satisfactory and 1 "non-satisfactory" which includes not comfortable. Living arrangement was recoded as living alone, with the spouse, with children, and living with others. Age was categorized as 60-69, 70-79, and $80+$ years. Sex was categorized as Men and Women. Educational status was categorized as no schooling, below 5 years of schooling, 6-10 years of schooling, and 11 and above years of schooling. Working status for the last year was categorized as no and yes. Marital status was categorized as not in union "included never married, widowed, divorced and separated" and currently in a union.

\section{Statistical analysis}

Descriptive statistics and bivariate analysis were performed to present the preliminary estimates. For finding the association between various health outcomes over explanatory variables, the binary logistic regression model [41] was used separately for men and women. While applying logistic regression, outcome variables were recoded in binary forms $(0$ and 1$)$. For instance self-rated health ( 0 "good" and 1 "poor"), psychological health (0 "high" and 1 "low"), subjective well-being (0 "high" and 1 "low"), IADL (0 "high" and 1 "low"), ADL (0 "high" and 1 "low") and cognitive ability (0 "high" and 1 "low"). The main explanatory variable for the study 
was "feeling about present living arrangement" which was recoded as satisfactory and not-satisfactory.

The equation for logistic distribution is as follows:-

$$
\ln \left(\frac{\pi}{1-\pi}\right)=\alpha+\beta_{1} X_{1}+\beta_{2} X_{2}+\beta_{3} X_{3} \ldots \beta_{n} X_{n}
$$

Where, $\beta_{0}, \ldots ., \beta_{M}$, are the regression coefficients indicating the relative effect of a particular explanatory variable on the outcome variables. These coefficients change as per the context in the analysis in the study. STATA 14 was used to carry out the analysis [42].

\section{Results}

Figure 2 depicts the percentage distribution of older adults who were dissatisfied with their present living arrangement, by sex. Findings from this figure suggested that, out of the total older adults living alone, the highest proportion of women reported dissatisfaction with their present living arrangement. Higher percentage of older men $(22.8 \%)$ and women $(30.8 \%)$ reported to be dissatisfied by their present living arrangement if they were living alone.

The characteristics of the target population in this study are summarized in Table 1. Around 63\% of the older adults from the dataset belong to the age group of 60-69. More than half of the subjects under study were women. A total of 1050 (11.44\%) older adults have reported their dissatisfaction with their living arrangements. Besides, around $6.06 \%$ of the older adults were living alone whereas around $14.58 \%$ of them were living with spouse only.

Table 2 depicts the mean scores for six different health conditions by background characteristic of the study population and the values closer to one indicated a poor state of health and vice versa. Findings from this study suggested that the older adults who were not satisfied with their current living arrangements acquired higher mean scores of different health conditions as compared to the ones who were quite satisfied with the same. The mean score for poor self-rated health, low psychological health, low subjective well-being, and low cognitive ability was higher among older adults living alone. However, the same for low ADL and low IADL was higher among older adults living with others. Findings also suggested that the mean scores for all the six different health conditions were higher among the oldest old of 80 years and above and lowest among older individuals belonging to the age group of 60-69 years. Apart from this, the mean scores for all six health conditions were higher among women, indicating that women were in a poor state of health and well-being than men.

The adjusted odds ratio (OR) for the relationship between living arrangements, their feeling about present living arrangements, and three different health conditions viz. poor self-rated health, low general health, and low subjective well-being, are shown in Table 3. Findings from this table suggested that both men and women who were dissatisfied with their present living arrangements acquired a higher chance of experiencing poor self-rated health, as compared to those who were satisfied with it, which has remained significant [OR:4.45, $3.25 \sim 6.09$ and OR:3.32, $2.54 \sim 4.34$ ] in the model. Also, older men and women who were dissatisfied with their living arrangement acquired almost two times higher odds [OR: 2.15, $1.61 \sim 2.86$ and OR: 1.99, $1.57 \sim 2.53, p$ value $<0.05$ ] of having low psychological health than older adults who were satisfied with it.

Similarly, older adults who were dissatisfied with their living arrangements were three times more likely to have low subjective well-being than their counterparts [OR: 3.37, $2.54 \sim 4.45$ and OR: 3.03, $2.36 \sim 3.38$ ]. Apart from this, women living with children were $34 \%$ more likely [OR: $1.34,1.01 \sim 1.79, p$-value $<0.05$ ] to have poor selfrated health as compared to the older women living alone. However, in the case of men there lies no significant association with poor self-rated health. Men living

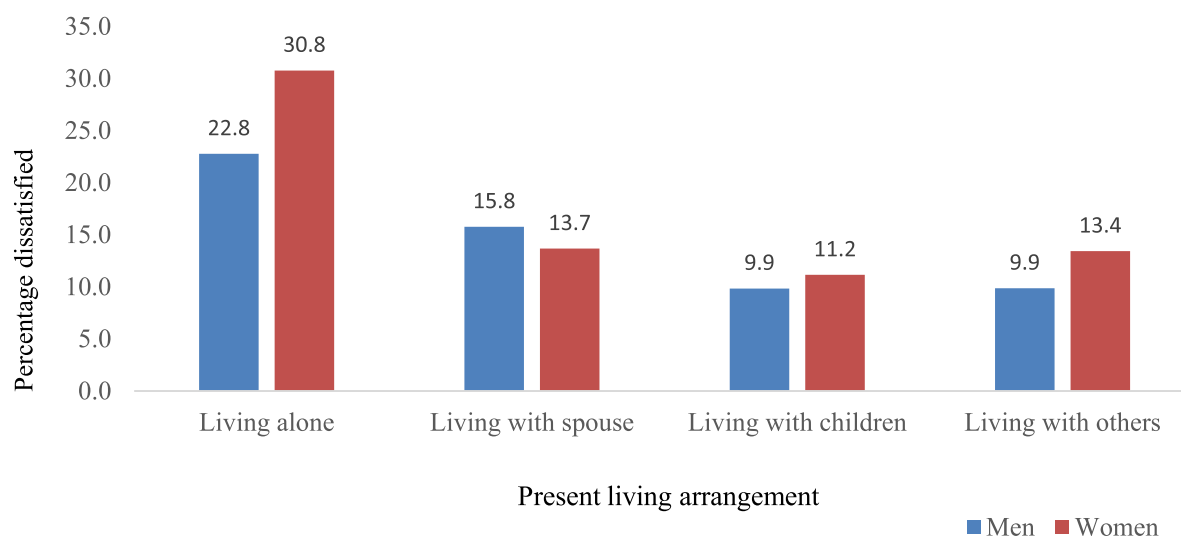

Fig. 2 Percentage distribution of older men and women who were dissatisfied by their present living arrangement 
Table 1 Background characteristics of the study participants $(N=9181)$

Background Variables

No

Yes

Low psychological health

No

Yes

7027

2154

Low subjective well-being

No

Yes

Low ADL

No

Yes

Low IADL

No

Yes

Low cognitive ability

No

Yes

Age (in years)

60-69

70-79

$80+$

Sex

Men

Women

Educational status (in years)

None

Below 5 years

6 to 10 years

$11+$ years

No

\section{Marital status}

Not in union

Currently in union

Feeling about present living arrangement

Satisfactory

Non satisfactory

Living arrangement

Alone

with spouse

1462

21.9

With children

6480

70.6

Others 
Table 1 Background characteristics of the study participants $(N=9181)$ (Continued)

\begin{tabular}{|c|c|c|}
\hline Background Variables & Sample & Percentage \\
\hline \multicolumn{3}{|l|}{ Religion } \\
\hline Hindu & 7389 & 80.5 \\
\hline Muslim & 617 & 6.7 \\
\hline Sikh & 771 & 8.4 \\
\hline Others & 404 & 4.4 \\
\hline \multicolumn{3}{|l|}{ Caste } \\
\hline Scheduled Caste & 1802 & 19.6 \\
\hline Scheduled Tribe & 470 & 5.1 \\
\hline Other Backward Class & 3190 & 34.8 \\
\hline Others & 3719 & 40.5 \\
\hline \multicolumn{3}{|l|}{ Place of residence } \\
\hline Rural & 4784 & 52.1 \\
\hline Urban & 4397 & 47.9 \\
\hline \multicolumn{3}{|l|}{ Wealth status } \\
\hline Poorest & 1758 & 19.2 \\
\hline Poorer & 1838 & 20.0 \\
\hline Middle & 1823 & 19.9 \\
\hline Richer & 1844 & 20.1 \\
\hline Richest & 1918 & 20.9 \\
\hline \multicolumn{3}{|l|}{ State } \\
\hline Kerala & 1338 & 14.6 \\
\hline Himachal Pradesh & 1452 & 15.8 \\
\hline Punjab & 1249 & 13.6 \\
\hline West Bengal & 1112 & 12.1 \\
\hline Orissa & 1448 & 15.8 \\
\hline Maharashtra & 1251 & 13.6 \\
\hline Tamil Nadu & 1331 & 14.5 \\
\hline Total & 9181 & 100 \\
\hline
\end{tabular}

with spouse only are less likely to have poor psychological health as compared to those living alone [OR: $0.47,0.26 \sim 0.86, p$-value $<0.05]$. Older men aged 70-79 years acquired significantly higher odds [OR: 1.23, $1.01 \sim 1.49$ ] of having poor self-rated health than the one belonging to the lower age group. Similarly, older women of age 70 years and above had a significantly higher chance of experiencing low psychological health and low subjective well-being, as compared to their counterparts. Both men and women with higher educational status had a lesser chance of experiencing poor self-rated health, low psychological health, and low subjective well-being as compared to the one with no formal education at all. Working men were less likely to have low psychological health and low subjective well-being [OR: 0.77, $0.6 \sim 0.97$ and OR: $0.55,0.43 \sim 0.69]$. Apart from this, wealth status and states were also significantly associated with the occurrence of the three different health outcomes under study, respectively.

The adjusted ORs for the relationship between living arrangements, their feeling about present living arrangements, and three different health conditions viz. low ADL, low IADL, low cognitive ability are shown in Table 4. Findings suggested that older adults who were dissatisfied with their current living arrangement had higher odds of having low ADL [OR: 1.77, $1.2 \sim 2.62$ and OR: $1.59,1.17 \sim 2.18$ ] and low IADL [OR: 1.32, $1.03 \sim$ 1.69 and OR: $1.57,1.24 \sim 1.98]$ as compared to those who were satisfied with it, which has remained significant in the model. On considering the presence of low cognitive ability among the study subjects, findings showed that men were not significantly associated with the same, whereas women who were dissatisfied with their present living arrangement had higher odds [OR: $1.44,1.13 \sim 1.82$ ] of having low cognitive ability in 
Table 2 Mean scores for six different health conditions over background characteristics among older adults $(N=9181)$

\begin{tabular}{|c|c|c|c|c|c|c|}
\hline \multirow[t]{2}{*}{ Variables } & $\begin{array}{l}\text { Poor self-rated } \\
\text { health }\end{array}$ & $\begin{array}{l}\text { Low psychological } \\
\text { health }\end{array}$ & $\begin{array}{l}\text { Low subjective } \\
\text { well-being }\end{array}$ & Low ADL & Low IADL & $\begin{array}{l}\text { Low cognitive } \\
\text { ability }\end{array}$ \\
\hline & Mean & Mean & Mean & Mean & Mean & Mean \\
\hline \multicolumn{7}{|c|}{ Feeling about present living arrangement } \\
\hline Satisfactory & 0.52 & 0.20 & 0.22 & 0.07 & 0.55 & 0.58 \\
\hline Non satisfactory & 0.81 & 0.47 & 0.63 & 0.12 & 0.70 & 0.74 \\
\hline \multicolumn{7}{|l|}{ Living arrangement } \\
\hline Alone & 0.57 & 0.33 & 0.40 & 0.03 & 0.36 & 0.63 \\
\hline With spouse & 0.50 & 0.21 & 0.26 & 0.04 & 0.48 & 0.51 \\
\hline With children & 0.56 & 0.23 & 0.25 & 0.08 & 0.60 & 0.61 \\
\hline Others & 0.62 & 0.26 & 0.31 & 0.10 & 0.59 & 0.69 \\
\hline \multicolumn{7}{|l|}{ Age (in years) } \\
\hline $60-69$ & 0.50 & 0.20 & 0.23 & 0.03 & 0.47 & 0.53 \\
\hline $70-79$ & 0.62 & 0.27 & 0.30 & 0.10 & 0.67 & 0.68 \\
\hline $80+$ & 0.70 & 0.35 & 0.39 & 0.25 & 0.86 & 0.79 \\
\hline \multicolumn{7}{|l|}{ Sex } \\
\hline Men & 0.52 & 0.21 & 0.24 & 0.06 & 0.56 & 0.53 \\
\hline Women & 0.58 & 0.26 & 0.29 & 0.09 & 0.57 & 0.66 \\
\hline \multicolumn{7}{|c|}{ Educational status (in years) } \\
\hline None & 0.61 & 0.31 & 0.36 & 0.09 & 0.69 & 0.71 \\
\hline Below 5 years & 0.57 & 0.22 & 0.24 & 0.08 & 0.51 & 0.64 \\
\hline 6 to 10 years & 0.45 & 0.13 & 0.14 & 0.04 & 0.40 & 0.41 \\
\hline $11+$ years & 0.41 & 0.08 & 0.10 & 0.04 & 0.26 & 0.31 \\
\hline \multicolumn{7}{|l|}{ Working status } \\
\hline No & 0.58 & 0.25 & 0.28 & 0.09 & 0.61 & 0.62 \\
\hline Yes & 0.47 & 0.20 & 0.24 & 0.01 & 0.43 & 0.53 \\
\hline \multicolumn{7}{|l|}{ Marital status } \\
\hline Not in union & 0.61 & 0.29 & 0.33 & 0.11 & 0.63 & 0.69 \\
\hline Currently in union & 0.51 & 0.20 & 0.23 & 0.05 & 0.52 & 0.54 \\
\hline \multicolumn{7}{|l|}{ Religion } \\
\hline Hindu & 0.53 & 0.26 & 0.28 & 0.07 & 0.57 & 0.60 \\
\hline Muslim & 0.67 & 0.23 & 0.30 & 0.12 & 0.57 & 0.67 \\
\hline Sikh & 0.66 & 0.08 & 0.12 & 0.06 & 0.62 & 0.56 \\
\hline Others & 0.61 & 0.16 & 0.22 & 0.07 & 0.31 & 0.64 \\
\hline \multicolumn{7}{|l|}{ Caste } \\
\hline Scheduled Caste & 0.60 & 0.28 & 0.34 & 0.08 & 0.63 & 0.66 \\
\hline Scheduled Tribe & 0.46 & 0.32 & 0.35 & 0.06 & 0.64 & 0.71 \\
\hline Other Backward Class & 0.53 & 0.26 & 0.28 & 0.08 & 0.53 & 0.56 \\
\hline Others & 0.56 & 0.17 & 0.20 & 0.07 & 0.55 & 0.58 \\
\hline \multicolumn{7}{|l|}{ Place of residence } \\
\hline Rural & 0.57 & 0.25 & 0.28 & 0.08 & 0.59 & 0.63 \\
\hline Urban & 0.51 & 0.19 & 0.22 & 0.07 & 0.48 & 0.52 \\
\hline \multicolumn{7}{|l|}{ Wealth status } \\
\hline Poorest & 0.62 & 0.37 & 0.47 & 0.08 & 0.67 & 0.71 \\
\hline Poorer & 0.56 & 0.29 & 0.32 & 0.07 & 0.59 & 0.65 \\
\hline
\end{tabular}


Table 2 Mean scores for six different health conditions over background characteristics among older adults ( $N=9181)$ (Continued)

\begin{tabular}{|c|c|c|c|c|c|c|}
\hline \multirow[t]{2}{*}{ Variables } & $\begin{array}{l}\text { Poor self-rated } \\
\text { health }\end{array}$ & $\begin{array}{l}\text { Low psychological } \\
\text { health }\end{array}$ & $\begin{array}{l}\text { Low subjective } \\
\text { well-being }\end{array}$ & Low ADL & Low IADL & $\begin{array}{l}\text { Low cognitive } \\
\text { ability }\end{array}$ \\
\hline & Mean & Mean & Mean & Mean & Mean & Mean \\
\hline Middle & 0.53 & 0.20 & 0.21 & 0.08 & 0.55 & 0.60 \\
\hline Richer & 0.49 & 0.15 & 0.15 & 0.06 & 0.51 & 0.49 \\
\hline Richest & 0.55 & 0.09 & 0.09 & 0.07 & 0.44 & 0.49 \\
\hline \multicolumn{7}{|l|}{ State } \\
\hline Kerala & 0.67 & 0.14 & 0.15 & 0.10 & 0.34 & 0.66 \\
\hline Himachal Pradesh & 0.46 & 0.17 & 0.15 & 0.07 & 0.60 & 0.54 \\
\hline Punjab & 0.67 & 0.07 & 0.11 & 0.05 & 0.60 & 0.55 \\
\hline West Bengal & 0.78 & 0.29 & 0.48 & 0.11 & 0.69 & 0.82 \\
\hline Orissa & 0.47 & 0.37 & 0.35 & 0.09 & 0.71 & 0.69 \\
\hline Maharashtra & 0.41 & 0.23 & 0.34 & 0.04 & 0.48 & 0.55 \\
\hline Tamil Nadu & 0.46 & 0.36 & 0.32 & 0.06 & 0.53 & 0.41 \\
\hline India & 0.55 & 0.23 & 0.27 & 0.07 & 0.56 & 0.60 \\
\hline
\end{tabular}

Poor self-rated health (coded in binary form i.e. 1 "poor or Fair" and 0 "Excellent, very good and good")

Low psychological health: General Health Scale (coded in binary form i.e. 1 "scores 5 or less" and 0 "scores more than 6")

Low subjective well-being (coded in binary form i.e. 1 "scores of 5 or less" and 0 "scores 6+")

Low ADL: Activities of Daily living (coded in binary i.e. 1 "scores of 5 or less" and 0 "scores 6+")

Low IADL: Instrumental Activities of Daily living (coded in binary i.e. 1 "scores of 5 or less" and 0 "scores 6+")

Low cognitive ability (coded in binary i.e. 1 "scores of 4 or less" and 0 "scores 5+")

comparison to their counterparts. Older adults living with children or other family members were more likely to have low ADL [OR: 5.16, $1.2 \sim 22.18$ and OR: 2.72, $1.63 \sim 4.51$; OR: $5.18,1.13 \sim 23.76$ and OR: $2.87,1.59 \sim$ 5.18] and low IADL [OR: 4.7, $2.91 \sim 7.59$ and OR: 4.49, $3.43 \sim 5.87$; OR: $4.11,2.41 \sim 6.99)$ and OR: $3.9,2.78 \sim$ 5.48 ] as compared to those who were living alone. Men and women living with a spouse had three times and two times [OR: 3.51, $2.13 \sim 5.76$ and OR: 2.14, $1.51 \sim$ 3.02, $p$-value $<0.05$ ] higher chance of having low IADL as compared to that of one living alone. Older adults including both men and women aged 80 years and above acquired significantly higher odds [OR: 4.21, $2.65 \sim 6.69$ and OR: 4.50, 3.04 6.66, $p$-value $<0.05$ ] of having poor self-rated health than the one belonging to the lower age group. Similarly, older women of age 70 years and above had a significantly higher chance of experiencing low ADL, low IADL, and low cognitive ability, as compared to the older adults belonging to the age group of 60-69, respectively. Both working men and women were less likely to have low ADL [OR: 0.29, $0.15 \sim 0.53$ and OR: $0.14,0.03 \sim 0.64, p$-value $<0.05]$ and low IADL [OR: 0.46, $0.38 \sim 0.55$ and OR: $0.49,0.37 \sim 0.65, p$-value $<0.05]$ as compared to their counterparts.

\section{Discussion}

The present study explored how the dissatisfaction with living arrangements of older men and women affects their health. It is found that a large number of older adults $(12.5 \%)$ are dissatisfied with their current living arrangement especially, those older adults who live entirely on their own and it is significantly associated with negative health outcomes. The findings are consistent with previous studies suggesting that living alone is a significant predictor of reporting problems on mobility, pain/discomfort, and anxiety/depression [43]. Results demonstrate that the co-residential living arrangement is positively associated with older people's satisfaction. The results also show that the satisfaction of the older men and women is low when they live alone, but they are satisfied when they live with their spouses or children, or others. In such cases, independent children and society need to encourage the older parents to get married again for late-life support and well-being.

A wealth of studies have shown that living arrangements are critical to health in old age [44-47]. Results from this study also show that older people's dissatisfaction with living arrangements is closely related to adverse health outcomes with several indicators of health, SWB, ADL, IADL, and cognitive ability among the older adults in India. We found that in comparison with men and those living alone, women living with a spouse /others were more likely to report having excellent or very good health. Though studies have shown that having family members' support reduces the effect of any type of problems on older adults and it gives them the strength and positive mental attitude to handle their daily lives $[7,21,48]$. On the other hand, previous studies on older adults living alone showed that they often have better health than those living with spouse and 
Table 3 Logistic Regression estimates for poor self-rated health, low psychological health, and low subjective well-being among older adults (aged 60 years and above), sex-stratified

\begin{tabular}{|c|c|c|c|c|c|c|}
\hline \multirow[t]{3}{*}{ Variables } & \multicolumn{2}{|c|}{ Poor self-rated health } & \multicolumn{2}{|c|}{ Low psychological health } & \multicolumn{2}{|c|}{ Low subjective well-being } \\
\hline & OR $(95 \% \mathrm{Cl})$ & OR $(95 \% \mathrm{Cl})$ & OR $(95 \% \mathrm{Cl})$ & OR $(95 \% \mathrm{Cl})$ & OR $(95 \% \mathrm{Cl})$ & OR $(95 \% \mathrm{Cl})$ \\
\hline & Men & Women & Men & Women & Men & Women \\
\hline \multicolumn{7}{|c|}{ Feeling about present living arrangement } \\
\hline Satisfactory & Ref. & Ref. & Ref. & Ref. & Ref. & Ref. \\
\hline Non satisfactory & $4.45^{*}(3.25,6.09)$ & $3.32 *(2.54,4.34)$ & $2.15^{*}(1.61,2.86)$ & $1.99^{*}(1.57,2.53)$ & $3.37^{*}(2.54,4.45)$ & $3.03^{*}(2.36,3.88)$ \\
\hline \multicolumn{7}{|l|}{ Living arrangement } \\
\hline Alone & Ref. & Ref. & Ref. & Ref. & Ref. & Ref. \\
\hline With spouse & $1.17(0.65,2.09)$ & $1.32(0.90,1.92)$ & $0.47^{*}(0.26,0.86)$ & $0.78(0.50,1.21)$ & $0.71(0.36,1.39)$ & $1.15(0.76,1.74)$ \\
\hline With children & $1.40(0.80,2.44)$ & $1.34^{*}(1.01,1.79)$ & $0.57(0.32,1.01)$ & $1.13(0.83,1.52)$ & $0.74(0.39,1.42)$ & $1.08(0.80,1.46)$ \\
\hline Others & $1.31(0.70,2.46)$ & $1.42(0.98,2.07)$ & $0.91(0.47,1.75)$ & $1.35(0.90,2.03)$ & $1.12(0.54,2.33)$ & $1.28(0.86,1.9)$ \\
\hline \multicolumn{7}{|l|}{ Age (in years) } \\
\hline $60-69$ & Ref. & Ref. & Ref. & Ref. & Ref. & Ref. \\
\hline $70-79$ & $1.23^{*}(1.01,1.49)$ & $1.12(0.93,1.36)$ & $0.97(0.76,1.23)$ & $1.24^{*}(1.00,1.53)$ & $0.92(0.73,1.17)$ & $1.31 *(1.06,1.60)$ \\
\hline $80+$ & $1.22(0.88,1.67)$ & $1.22(0.89,1.67)$ & $1.29(0.92,1.83)$ & $1.62 *(1.19,2.2)$ & $1.31(0.94,1.84)$ & $1.78^{*}(1.33,2.38)$ \\
\hline \multicolumn{7}{|c|}{ Educational status (in years) } \\
\hline No schooling & Ref. & Ref. & Ref. & Ref. & Ref. & Ref. \\
\hline Below 5 years & $0.99(0.79,1.24)$ & $0.80(0.63,1.00)$ & $0.73^{*}(0.57,0.95)$ & $0.74 *(0.58,0.96)$ & $0.70 *(0.55,0.90)$ & $0.63^{*}(0.50,0.79)$ \\
\hline 6 to 10 years & $0.08(0.63,1.01)$ & $0.51 *(0.39,0.65)$ & $0.53^{*}(0.39,0.71)$ & $0.46^{*}(0.32,0.67)$ & $0.45 *(0.34,0.60)$ & $0.54^{*}(0.39,0.73)$ \\
\hline $11+$ years & $0.55^{*}(0.38,0.78)$ & $0.45^{*}(0.27,0.74)$ & $0.42^{*}(0.25,0.71)$ & $0.44^{*}(0.20,0.98)$ & $0.43^{*}(0.24,0.75)$ & $0.59(0.31,1.15)$ \\
\hline \multicolumn{7}{|l|}{ Working status } \\
\hline No & Ref. & Ref. & Ref. & Ref. & Ref. & Ref. \\
\hline Yes & $0.86(0.71,1.04)$ & $0.78(0.6,1.02)$ & $0.77^{*}(0.6,0.97)$ & $0.87(0.65,1.17)$ & $0.55^{*}(0.43,0.69)$ & $1.15(0.87,1.52)$ \\
\hline \multicolumn{7}{|l|}{ Marital status } \\
\hline Not in union & Ref. & Ref. & Ref. & Ref. & Ref. & Ref. \\
\hline Currently in union & $0.95(0.74,1.21)$ & $0.94(0.77,1.14)$ & $1.11(0.83,1.47)$ & $1.01(0.8,1.27)$ & $0.98(0.74,1.29)$ & $0.91(0.73,1.14)$ \\
\hline \multicolumn{7}{|l|}{ Religion } \\
\hline Hindu & Ref. & Ref. & Ref. & Ref. & Ref. & Ref. \\
\hline Muslim & $1.17(0.81,1.68)$ & $1.09(0.77,1.54)$ & $1.17(0.76,1.79)$ & $1.25(0.9,1.76)$ & $1.40(0.89,2.19)$ & $1.14(0.82,1.59)$ \\
\hline Sikh & $1.16(0.74,1.80)$ & $0.87(0.58,1.29)$ & $1.08(0.53,2.20)$ & $0.90(0.46,1.76)$ & $0.97(0.51,1.83)$ & $1.37(0.81,2.33)$ \\
\hline Others & $1.07(0.7,1.66)$ & $1.21(0.8,1.81)$ & $0.85(0.48,1.50)$ & $1.04(0.66,1.62)$ & $1.2(0.65,2.2)$ & $1.53^{*}(1.03,2.26)$ \\
\hline \multicolumn{7}{|l|}{ Caste } \\
\hline Scheduled Caste & Ref. & Ref. & Ref. & Ref. & Ref. & Ref. \\
\hline Scheduled Tribe & $0.89(0.58,1.38)$ & $0.82(0.55,1.21)$ & $1.12(0.72,1.76)$ & $0.8(0.54,1.17)$ & $1.03(0.65,1.62)$ & $0.93(0.63,1.37)$ \\
\hline Other Backward Class & $1.05(0.81,1.36)$ & $1.14(0.89,1.48)$ & $0.88(0.65,1.18)$ & $0.71 *(0.54,0.93)$ & $0.96(0.71,1.3)$ & $1.15(0.88,1.51)$ \\
\hline Others & $0.90(0.71,1.16)$ & $1.15(0.91,1.47)$ & $0.78(0.58,1.05)$ & $0.83(0.64,1.09)$ & $0.76(0.58,1.02)$ & $0.89(0.69,1.15)$ \\
\hline \multicolumn{7}{|l|}{ Place of residence } \\
\hline Rural & Ref. & Ref. & Ref. & Ref. & Ref. & Ref. \\
\hline Urban & $0.98(0.81,1.17)$ & $0.96(0.80,1.14)$ & $0.95(0.75,1.20)$ & $0.92(0.75,1.13)$ & $1.20(0.96,1.51)$ & $1.06(0.88,1.28)$ \\
\hline \multicolumn{7}{|l|}{ Wealth status } \\
\hline Poorest & Ref. & Ref. & Ref. & Ref. & Ref. & Ref. \\
\hline Poorer & $0.97(0.74,1.28)$ & $0.74^{*}(0.57,0.96)$ & $1.15(0.86,1.53)$ & $1.18(0.91,1.53)$ & $0.97(0.74,1.27)$ & $0.71 *(0.55,0.92)$ \\
\hline Middle & $0.78(0.58,1.06)$ & $0.57^{*}(0.42,0.76)$ & $0.95(0.68,1.33)$ & $0.85(0.63,1.15)$ & $0.64^{*}(0.46,0.88)$ & $0.55^{*}(0.41,0.74)$ \\
\hline Richer & $0.71^{*}(0.51,0.99)$ & $0.47^{*}(0.34,0.65)$ & $0.77(0.51,1.15)$ & $0.75(0.53,1.07)$ & $0.38^{*}(0.26,0.55)$ & $0.49^{*}(0.35,0.68)$ \\
\hline
\end{tabular}


Table 3 Logistic Regression estimates for poor self-rated health, low psychological health, and low subjective well-being among older adults (aged 60 years and above), sex-stratified (Continued)

\begin{tabular}{|c|c|c|c|c|c|c|}
\hline \multirow[t]{3}{*}{ Variables } & \multicolumn{2}{|c|}{ Poor self-rated health } & \multicolumn{2}{|c|}{ Low psychological health } & \multicolumn{2}{|c|}{ Low subjective well-being } \\
\hline & OR $(95 \% \mathrm{Cl})$ & OR $(95 \% \mathrm{Cl})$ & OR $(95 \% \mathrm{CI})$ & OR $(95 \% \mathrm{Cl})$ & OR $(95 \% \mathrm{CI})$ & OR $(95 \% \mathrm{Cl})$ \\
\hline & Men & Women & Men & Women & Men & Women \\
\hline Richest & $0.70(0.48,1.03)$ & $0.65^{*}(0.45,0.93)$ & $0.52^{*}(0.31,0.87)$ & $0.66^{*}(0.43,1.00)$ & $0.23^{*}(0.13,0.38)$ & $0.40^{*}(0.27,0.58)$ \\
\hline \multicolumn{7}{|l|}{ State } \\
\hline Kerala & Ref. & Ref. & Ref. & Ref. & Ref. & Ref. \\
\hline Himachal Pradesh & $0.54^{*}(0.38,0.78)$ & $0.38^{*}(0.27,0.55)$ & $1.45(0.86,2.44)$ & $1.03(0.67,1.57)$ & $1.28(0.76,2.15)$ & $0.94(0.61,1.45)$ \\
\hline Punjab & $1.15(0.75,1.76)$ & $0.92(0.62,1.36)$ & $0.64(0.31,1.32)$ & $0.27^{*}(0.15,0.48)$ & $0.74(0.39,1.41)$ & $0.64(0.39,1.08)$ \\
\hline West Bengal & $1.63^{*}(1.13,2.37)$ & $1.26(0.88,1.80)$ & $2.60^{*}(1.62,4.16)$ & $1.29(0.90,1.85)$ & $4.38^{*}(2.83,6.79)$ & $4.00 *(2.81,5.68)$ \\
\hline Orissa & $0.35^{*}(0.24,0.5)$ & $0.2^{*}(0.14,0.29)$ & $3.72 *(2.33,5.93)$ & $2.12 *(1.45,3.10)$ & $2.06^{*}(1.33,3.19)$ & $1.49 *(1.02,2.19)$ \\
\hline Maharashtra & $0.31 *(0.23,0.43)$ & $0.25^{*}(0.18,0.34)$ & $2.34^{*}(1.52,3.62)$ & $1.33(0.94,1.88)$ & $2.34^{*}(1.55,3.54)$ & $2.62^{*}(1.88,3.64)$ \\
\hline Tamil Nadu & $0.70^{*}(0.49,0.98)$ & $0.48^{*}(0.35,0.66)$ & $7.38^{*}(4.57,11.92)$ & $4.79 *(3.32,6.91)$ & $2.55^{*}(1.63,3.99)$ & $2.12 *(1.48,3.04)$ \\
\hline
\end{tabular}

Poor self-rated health (coded in binary form i.e. 1 "poor or fair" and 0 "Excellent, very good and good")

Low psychological health: General Health Scale (coded in binary form i.e. 1 "scores 5 or less" and 0 "scores more than 6")

Low subjective well-being (coded in binary form i.e. 1 "scores of 5 or less" and 0 "scores 6+")

*if $p<0.05$

Ref Reference, OR Odds Ratio, $\mathrm{Cl}$ Confidence Interval

The analysis is controlled for state level variations

others which is true for older adults who can live alone by choice with sufficient resources [49-51]. However, when asked about the feeling of their living arrangement our study found that they were not satisfactory. This finding indicates that living alone, among older adults, may be a marker for improved health and greater functional independence.

Previous studies found that mental health status was good for those living with family members (spouse or children) compared with older adults living alone [52-54]. Consistently, our findings showed that men living alone had low psychological health while the association was insignificant in the case of women, though when functional health was considered in relation with their living arrangements, findings showed that both men and women co-residing with spouse or children or others had lower ADL and IADL functioning in comparison to those lived alone with higher odds among older men. Thus, the gender variations we observed between living arrangements and health status are also worth debating. One study conducted in the United States found that living alone can be beneficial for the SWB of older people [55].

Furthermore, the current finding that older men and women in the present study who lived alone were more likely to have better outcomes in ADL and IADL compared to those who lived with spouse and children was in variance with multiple studies that showed various health disadvantages of living alone, for example, a recent study reported that the occurrence of functional disabilities among older individuals was largely associated with lack of relatives and social contacts [56]. Nevertheless, consistent with our finding, studies showed similar results [57, 58], suggesting that those who lived alone were less likely to encounter ADL decline at baseline, thus indicating a need for further investigation on this particular area. Moreover, there was no significant difference found in the present study between men and women in their cognitive health associated with the living arrangement. Concordantly, while many reported no significant differences $[59,60]$, few studies stated significant gender-based differences in cognition and psychological wellbeing due to factors such as widowhood and lack financial support [61-64].

In summary, consistent with some recent micro-level work on population aging in India that has found that living arrangements and care and support for older adults are a core determinant of their health status [47, 65-67], the results of this study also showed that living arrangements and feeling about living arrangement played a significant role in predicting health outcomes in older adult life.

Our findings, as with any study, should be considered in light of their potential limitations. We depend on secondary cross-sectional data analysis which is unable to address reverse causality issues. However, findings based on self-reported data are subject to recall bias and reporting errors are possible, and therefore a single dependence on these responses could not adequately capture the relationship between the older adults' living condition and its related health conditions. However, the study has a large sample size with a good response rate, that advances knowledge on living arrangements and health status of the older adults in a culture that values 
Table 4 Logistic Regression estimates for low ADL, low IADL and Low cognitive ability among older adults (aged 60 years and above), sex-stratified

\begin{tabular}{|c|c|c|c|c|c|c|}
\hline \multirow[t]{3}{*}{ Variables } & \multicolumn{2}{|l|}{ Low ADL } & \multicolumn{2}{|l|}{ Low IADL } & \multicolumn{2}{|c|}{ Low cognitive ability } \\
\hline & OR $(95 \% \mathrm{Cl})$ & OR $(95 \% \mathrm{Cl})$ & OR $(95 \% \mathrm{Cl})$ & OR $(95 \% \mathrm{Cl})$ & OR $(95 \% \mathrm{Cl})$ & OR $(95 \% \mathrm{Cl})$ \\
\hline & Men & Women & Men & Women & Men & Women \\
\hline \multicolumn{7}{|c|}{ Feeling about present living arrangement } \\
\hline Satisfactory & Ref. & Ref. & Ref. & Ref. & Ref. & Ref. \\
\hline Non satisfactory & $1.77^{*}(1.20,2.62)$ & $1.59 *(1.17,2.18)$ & $1.32 *(1.03,1.69)$ & $1.57^{*}(1.24,1.98)$ & $1.26(0.98,1.61)$ & $1.44^{*}(1.13,1.82)$ \\
\hline \multicolumn{7}{|l|}{ Living arrangement } \\
\hline Alone & Ref. & Ref. & Ref. & Ref. & Ref. & Ref. \\
\hline With spouse & $3.74(0.84,16.59)$ & $1.32(0.64,2.73)$ & $3.51^{*}(2.13,5.76)$ & $2.14^{*}(1.51,3.02)$ & $0.75(0.47,1.21)$ & $0.93(0.67,1.28)$ \\
\hline With children & $5.16^{*}(1.2,22.18)$ & $2.72 *(1.63,4.51)$ & $4.70^{*}(2.91,7.59)$ & $4.49 *(3.43,5.87)$ & $0.84(0.53,1.31)$ & $1.20(0.93,1.54)$ \\
\hline Others & $5.18^{*}(1.13,23.76)$ & $2.87^{*}(1.59,5.18)$ & $4.11^{*}(2.41,6.99)$ & $3.90 *(2.78,5.48)$ & $0.89(0.54,1.48)$ & $1.35(0.97,1.88)$ \\
\hline \multicolumn{7}{|l|}{ Age (in years) } \\
\hline $60-69$ & Ref. & Ref. & Ref. & Ref. & Ref. & Ref. \\
\hline $70-79$ & $1.83^{*}(1.21,2.76)$ & $1.93^{*}(1.40,2.67)$ & $1.37^{*}(1.13,1.67)$ & $2.16 *(1.77,2.64)$ & $1.33^{*}(1.09,1.61)$ & $1.51 *(1.24,1.85)$ \\
\hline $80+$ & $4.21^{*}(2.65,6.69)$ & $4.50 *(3.04,6.66)$ & $3.73^{*}(2.63,5.30)$ & $4.90 *(3.44,6.96)$ & $2.26^{*}(1.64,3.12)$ & $1.63^{*}(1.18,2.24)$ \\
\hline \multicolumn{7}{|c|}{ Educational status (in years) } \\
\hline No schooling & Ref. & Ref. & Ref. & Ref. & Ref. & Ref. \\
\hline Below 5 years & $1.35(0.86,2.12)$ & $0.72(0.48,1.1)$ & $0.66^{*}(0.53,0.83)$ & $0.53^{*}(0.43,0.66)$ & $0.84(0.67,1.06)$ & $0.65^{*}(0.52,0.81)$ \\
\hline 6 to 10 Years & $1.39(0.83,2.35)$ & $0.96(0.55,1.66)$ & $0.48 *(0.38,0.61)$ & $0.26^{*}(0.2,0.35)$ & $0.4^{*}(0.32,0.51)$ & $0.40 *(0.31,0.51)$ \\
\hline $11+$ years & $1.30(0.50,3.37)$ & $1.00(0.41,2.42)$ & $0.20^{*}(0.14,0.30)$ & $0.19^{*}(0.11,0.31)$ & $0.25^{*}(0.18,0.36)$ & $0.20 *(0.12,0.31)$ \\
\hline \multicolumn{7}{|l|}{ Working status } \\
\hline No & Ref. & Ref. & Ref. & Ref. & Ref. & Ref. \\
\hline Yes & $0.29 *(0.15,0.53)$ & $0.14^{*}(0.03,0.64)$ & $0.46^{*}(0.38,0.55)$ & $0.49 *(0.37,0.65)$ & $0.77^{*}(0.64,0.92)$ & $1.05(0.81,1.37)$ \\
\hline \multicolumn{7}{|l|}{ Marital status } \\
\hline Not in union & Ref. & Ref. & Ref. & Ref. & Ref. & Ref. \\
\hline Currently in union & $1.09(0.70,1.69)$ & $1.26(0.88,1.81)$ & $0.89(0.70,1.14)$ & $0.82(0.67,1.01)$ & $0.87(0.68,1.11)$ & $0.97(0.81,1.18)$ \\
\hline \multicolumn{7}{|l|}{ Religion } \\
\hline Hindu & Ref. & Ref. & Ref. & Ref. & Ref. & Ref. \\
\hline Muslim & $1.61(0.85,3.02)$ & $1.65^{*}(1.05,2.57)$ & $1.22(0.86,1.75)$ & $1.65^{*}(1.19,2.28)$ & $0.99(0.70,1.40)$ & $0.87(0.61,1.23)$ \\
\hline Sikh & $1.64(0.67,4.05)$ & $0.97(0.48,1.95)$ & $1.12(0.74,1.69)$ & $0.94(0.63,1.42)$ & $1.02(0.68,1.54)$ & $1.03(0.70,1.50)$ \\
\hline Others & $0.84(0.30,2.35)$ & $0.80(0.45,1.43)$ & $0.5^{*}(0.32,0.79)$ & $1.03(0.67,1.57)$ & $1.24(0.83,1.85)$ & $1.53^{*}(1.04,2.24)$ \\
\hline \multicolumn{7}{|l|}{ Caste } \\
\hline Scheduled Caste & Ref. & Ref. & Ref. & Ref. & Ref. & Ref. \\
\hline Scheduled Tribe & $0.87(0.38,2.00)$ & $0.85(0.38,1.86)$ & $1.21(0.79,1.86)$ & $0.74(0.49,1.11)$ & $1.49(0.98,2.27)$ & $1.09(0.72,1.66)$ \\
\hline Other Backward Class & $1.22(0.75,1.98)$ & $0.88(0.58,1.35)$ & $1.16(0.90,1.49)$ & $0.89(0.68,1.16)$ & $0.90(0.70,1.16)$ & $1.23(0.95,1.59)$ \\
\hline Others & $0.66(0.40,1.09)$ & $1.15(0.78,1.70)$ & $1.13(0.89,1.44)$ & $0.90(0.71,1.16)$ & $0.85(0.67,1.08)$ & $1.01(0.79,1.30)$ \\
\hline \multicolumn{7}{|l|}{ Place of residence } \\
\hline Rural & Ref. & Ref. & Ref. & Ref. & Ref. & Ref. \\
\hline Urban & $0.85(0.58,1.26)$ & $1.17(0.87,1.57)$ & $1.17(0.97,1.40)$ & $0.83^{*}(0.69,0.99)$ & $1.06(0.88,1.27)$ & $0.96(0.81,1.13)$ \\
\hline \multicolumn{7}{|l|}{ Wealth status } \\
\hline Poorest & Ref. & Ref. & Ref. & Ref. & Ref. & Ref. \\
\hline Poorer & $0.85(0.49,1.5)$ & $1.14(0.73,1.76)$ & $0.73^{*}(0.56,0.96)$ & $1.04(0.79,1.37)$ & $0.93(0.71,1.21)$ & $1.1(0.84,1.44)$ \\
\hline Middle & $1.13(0.6,2.11)$ & $0.88(0.54,1.45)$ & $0.77(0.57,1.04)$ & $0.80(0.59,1.09)$ & $0.77(0.57,1.04)$ & $0.94(0.70,1.26)$ \\
\hline Richer & $0.66(0.31,1.41)$ & $0.81(0.47,1.39)$ & $0.60^{*}(0.44,0.83)$ & $0.72^{*}(0.52,1.00)$ & $0.51^{*}(0.37,0.71)$ & $0.65^{*}(0.47,0.89)$ \\
\hline
\end{tabular}


Table 4 Logistic Regression estimates for low ADL, low IADL and Low cognitive ability among older adults (aged 60 years and above), sex-stratified (Continued)

\begin{tabular}{|c|c|c|c|c|c|c|}
\hline \multirow[t]{3}{*}{ Variables } & \multicolumn{2}{|l|}{ Low ADL } & \multicolumn{2}{|l|}{ Low IADL } & \multicolumn{2}{|c|}{ Low cognitive ability } \\
\hline & OR $(95 \% \mathrm{Cl})$ & OR (95\% Cl) & OR $(95 \% \mathrm{Cl})$ & OR $(95 \% \mathrm{Cl})$ & OR $(95 \% \mathrm{Cl})$ & OR $(95 \% \mathrm{Cl})$ \\
\hline & Men & Women & Men & Women & Men & Women \\
\hline Richest & $0.84(0.37,1.91)$ & $0.76(0.42,1.39)$ & $0.48^{*}(0.33,0.69)$ & $1.10(0.76,1.60)$ & $0.56^{*}(0.39,0.81)$ & $0.70^{*}(0.49,0.99)$ \\
\hline \multicolumn{7}{|l|}{ State } \\
\hline Kerala & Ref. & Ref. & Ref. & Ref. & Ref. & Ref. \\
\hline Himachal Pradesh & $1.67(0.80,3.47)$ & $0.73(0.41,1.31)$ & $2.38 *(1.64,3.44)$ & $3.52^{*}(2.46,5.04)$ & $0.38^{*}(0.27,0.53)$ & $0.59^{*}(0.41,0.85)$ \\
\hline Punjab & $0.77(0.30,1.96)$ & $0.38^{*}(0.20,0.72)$ & $2.51 *(1.64,3.85)$ & $3.03 *(2.00,4.57)$ & $0.46^{*}(0.30,0.70)$ & $0.46^{*}(0.31,0.67)$ \\
\hline West Bengal & $2.92 *(1.43,5.95)$ & $0.85(0.51,1.41)$ & $3.08 *(2.15,4.41)$ & $6.48 *(4.60,9.12)$ & $1.72^{*}(1.19,2.48)$ & $2.44^{*}(1.63,3.64)$ \\
\hline Orissa & $1.81(0.88,3.72)$ & $0.64(0.35,1.19)$ & $2.71 *(1.89,3.89)$ & $6.18^{*}(4.29,8.90)$ & $0.6^{*}(0.42,0.85)$ & $0.62 *(0.43,0.89)$ \\
\hline Maharashtra & $1.53(0.76,3.09)$ & $0.26^{*}(0.14,0.48)$ & $1.29(0.93,1.79)$ & $2.84^{*}(2.08,3.89)$ & $0.38^{*}(0.28,0.52)$ & $0.49^{*}(0.37,0.66)$ \\
\hline Tamil Nadu & $1.96(0.85,4.51)$ & $1.24(0.73,2.11)$ & $3.79 *(2.64,5.43)$ & $2.38 *(1.72,3.29)$ & $0.27^{*}(0.19,0.39)$ & $0.30 *(0.22,0.42)$ \\
\hline
\end{tabular}

Low ADL: Activities of Daily living (coded in binary i.e. 1 "scores of 5 or less" and 0 "scores 6+")

Low IADL: Instrumental Activities of Daily living (coded in binary i.e. 1 "scores of 5 or less" and 0 "scores 6+")

Low cognitive ability (coded in binary i.e. 1 "scores of 4 or less" and 0 "scores 5+")

*if $p<0.05$

Ref Reference, OR Odds Ratio, $\mathrm{Cl}$ Confidence Interval

The analysis is controlled for state level variations

the interdependence of the family; a cultural context that is widely predominant in developing countries.

\section{Conclusion}

The present study shows that, in terms of self-reported health status, general health, and subjective well-being, older people living alone and dissatisfied with their current living have poor health. Since filial obligations can play a pivotal role in reducing the discontent among older people, it is important to strengthen the values in care and support and enhance the capacity of the families providing incentives to minimize the financial and physical hardships of family members.

Further, the policymakers and health care professionals can engage those who are living alone with poor health status by allocating the resources that could target caregivers and close residents. Such efforts might include civic and community programming, and accessible and integrated models of health care delivery that address the problems of older individuals. The current evidence also suggests that further investigation is needed on why specific arrangements might be beneficial for health of the older individuals, so that other configurations of support can be developed such as institutional ones where both SWB and ADLs can be improved for both men and women and eliminate the intergenerational conflicts and gender differentials in caregiving.

\section{Abbreviations}

ADL: Activities of daily living; IADL: Instrumental activities of daily living; SRH: Self-rated health; BKPAl: Building a Knowledge Base on Population Aging in India; OR: Odds Ratio; Cl: Confidence Interval

\section{Supplementary Information}

The online version contains supplementary material available at https://doi. org/10.1186/s12889-021-11342-2.

Additional file 1. Appendix file.

Acknowledgments

Not applicable.

Authors' contributions

The concept was drafted by Shobhit Srivastava and TM; Shobhit Srivastava contributed to the analysis design. Shobhit Srivastava and TM advised on the paper and assisted in paper conceptualization. Shobhit Srivastava, Shubhojit Shaw, HC, NP and TM contributed in the comprehensive writing of the article. Shobhit Srivastava and TM contributed to subsequent revisions. All authors read and approved the final manuscript.

\section{Funding}

Authors did not receive any funding to carry out this research.

Availability of data and materials

The dataset generated and/or analysed during the current study is available in the repository, and accessible on request through http://www.isec.ac.in/

\section{Declarations}

Ethics approval and consent to participate

The survey agencies that conducted the field survey for the data collection have collected prior consent from all the respondents. All methods were carried out in accordance with relevant guidelines and regulations. Local ethics committee of Institute for Social and Economic Change, Bangalore, ruled that no formal ethics approval was required to carry out research from this data source.

\section{Consent for publication}

Not applicable.

Competing interests

The authors declare that they have no competing interest. 


\section{Author details}

'International Institute for Population Sciences, Mumbai, Maharashtra 400088, India. ${ }^{2}$ National Institute for Research in Reproductive Health, ICMR, Parel, Mumbai 400088, India. ${ }^{3}$ Department of Statistics, Dibrugarh University, Dibrugarh, Assam, India.

Received: 3 February 2021 Accepted: 21 June 2021

Published online: 06 July 2021

\section{References}

1. Deary IJ, Corley J, Gow AJ, Harris SE, Houlihan LM, Marioni RE, Penke L, Rafnsson SB, Starr JM. Age-associated cognitive decline. Br Med Bull. 2009; 92:135-52. https://doi.org/10.1093/bmb/ldp033. PMID: 19776035.

2. Mao X, Han WJ. Living arrangements and older adults' psychological wellbeing and life satisfaction in China: does social support matter? Fam Relat. 2018;67(4):567-84. https://doi.org/10.1111/fare.12326.

3. Muhammad T, Balachandran A, Srivastava S. Socio-economic and health determinants of preference for separate living among older adults: A crosssectional study in India. PLoS One. 2021;16(4 April):1-14.

4. Grundy E, Henretta JC. Between elderly parents and adult children: A new look at the intergenerational care provided by the "sandwich generation.". Ageing Soc. 2006;26(5):707-22. https://doi.org/10.1017/S0144686X06004934.

5. Attias-Donfut C. The dynamics of elderly support: the transmission of solidarity patterns between generations. Z Gerontol Geriatr. 2001;34(1):9-15. https://doi.org/10.1007/s003910170085.

6. Sugisawa H, Liang J, Liu X. Social networks, social support, and mortality among older people in Japan. J Gerontol. 1994;49(1):S3-13.

7. Zunzunegui MV, Béland F, Otero A. Support from children, living arrangements, self-rated health and depressive symptoms of older people in Spain. Int J Epidemiol. 2001;30(5):1090-9. https://doi.org/10.1093/ije/30.5.1 090.

8. Muhammad T, Srivastava S. Why rotational living is bad for older adults? Evidence from a cross-sectional study in india. Journal of Population Ageing. 2020:1-8.

9. Chen F. Household context and subjective well-being among the oldest old in China. J Fam Issues. 2010;16(6):1-25.

10. Rojas M. Intra-household arrangements and health satisfaction: evidence from Mexico; 2008.

11. Srivastava S, Muhammad T. In Pursuit of Happiness: Changes in Living Arrangement and Subjective Well-Being among Older Adults in India. Journal of Population Ageing. 2021:1-7.

12. Srivastava $S$, Chauhan $S$, Muhammad $T$, Jean $D$, Kumar $P$, Patel $R$, et al. Older adults ' psychological and subjective well-being as a function of household decision making role : evidence from cross-sectional survey. Clin Epidemiol Glob Heal. 2021;10:100676. https://doi.org/10.1016/j.cegh.2020.100676.

13. Chou KL, Chi I. Reciprocal relationship between social support and depressive symptoms among Chinese elderly. Aging Ment Health. 2003;7(3): 224-31. https://doi.org/10.1080/136031000101210.

14. Liu LJ, Guo Q. Life satisfaction in a sample of empty-nest elderly: a survey in the rural area of a mountainous county in China. Qual Life Res. 2008;17(6): 823-30. https://doi.org/10.1007/s11136-008-9370-1.

15. Muhammad T, Meher T. Association of late-life depression with cognitive impairment : evidence from a cross-sectional study among older adults in India. BMC Geriatr. 2021;21(1):1-13.

16. Lin $Y$, Xiao H, Lan X, Wen S, Bao S. Living arrangements and life satisfaction: mediation by social support and meaning in life. BMC Geriatr. 2020;20(1):18.

17. Thoits PA. Mechanisms linking social ties and support to physical and mental health. J Health Soc Behav. 2011;52(2):145-61. https://doi.org/10.11 77/0022146510395592.

18. Gaymu J, Springer S. How does Living Alone or with a Partner Influence Life Satisfaction among Older Men and Women in Europe? Popul Engl Ed. 2012; 67(1):43.

19. Fengler AP, Danigelis N, Little VC. Later life satisfaction and household structure:living with others and living alone. Ageing Soc. 1983;3(3):357-77. https://doi.org/10.1017/S0144686X00010230.

20. Kaufman M. Redefining success in America: a new theory of happiness and human development: University of Chicago Press; 2018.

21. Banjare $P$, Dwivedi R, Pradhan J. Factors associated with the life satisfaction amongst the rural elderly in Odisha, India. Health Qual Life Outcomes. 2015; 13(1):1-13.
22. Chou KL, Chi I. Successful aging among the young-old, old-old, and oldestold Chinese. Int J Aging Hum Dev. 2002;54(1):1-14. https://doi.org/10.2190/ 9K7T-6KXM-C0C6-3D64.

23. Lerner RM, Easterbrooks MA, Mistry J, Weiner IB. Handbook of psychology: developmental psychology; 2003.

24. Mindel $\mathrm{CH}$, Wright R. Satisfaction in multigenerational households. J Gerontol. 1982;37(4):483-9.

25. Jin $Q$, Pearce $P, H u H$. The study on the satisfaction of the elderly people living with their children. Soc Indic Res. 2018;140(3):1159-72. https://doi. org/10.1007/s11205-017-1803-1.

26. Bansod DW. Living arrangement and its effect on health of elderly in rural Maharashtra. Indian J Soc Work. 2009;70(1):55

27. Datta T. Living arrangements of the elderly in Kolkata. Genus Homo. 2019 3(1):61-72.

28. Veenhoven R. Why social policy needs subjective indicators. Soc Indic Res. 2002;58(1-3):33-46. https://doi.org/10.1023/A:1015723614574

29. Hunt SM, McEwen J. The development of a subjective health indicator. Sociol Health IIIn. 1980;2(3):231-46. https://doi.org/10.1111/1467-9566. ep11340686.

30. Liu YH, Chang HJ, Huang CC. The unmet activities of daily living (adl) needs of dependent elders and their related factors: an approach from both an individual- and area-level perspective. Int J Gerontol. 2012;6(3):163-8. https://doi.org/10.1016/j.ijge.2012.05.009.

31. UNFPA. Report on the status of elderly in selected states of India: building a knowledge base on ageing in India. New Delhi; 2012.

32. Srivastava S, Chauhan S, Patel R. Socio-Economic Inequalities in the Prevalence of Poor Self-Rated Health among Older Adults in India from 2004 to 2014 : A Decomposition Analysis; 2020.

33. Jacob KS, Bhugra D, Mann AH. General health questionnaire -12 : Psychometric properties and factor structure among Indian women living in the United Kingdom. Indian J Psychiatry. 1997;39(3):196-9.

34. Shidhaye $R$, Patel V. Association of socio-economic, gender and health factors with common mental disorders in women: a population-based study of 5703 married rural women in India. Int J Epidemiol. 2010;39(6): 1510-21. https://doi.org/10.1093/ije/dyq179.

35. Sell DH, Nagpal DR. Assessment of Subjective Well-being. Regional Health Paper; 1992

36. Muhammad T, Srivastava S, Sekher TV. Association of self-perceived income sufficiency with cognitive impairment among older adults: a populationbased study in India. BMC Psychiatry. 2021:21(1):100702.

37. Arokiasamy P. Uttamacharya, Kowal P, Chatterji S. age and socioeconomic gradients of health of Indian adults: an assessment of self-reported and biological measures of health. J Cross Cult Gerontol. 2016;31(2):193-211. https://doi.org/10.1007/s10823-016-9283-3.

38. Joe W, Perkins JM, Subramanian SV. Community involvement, trust, and health-related outcomes among older adults in India: a population-based, multilevel, cross-sectional study. Age Ageing. 2019;48(1):87-93. https://doi. org/10.1093/ageing/afy154

39. Skirbekk V, Loichinger $E$, Weber D. Variation in cognitive functioning as a refined approach to comparing aging across countries. Proc Natl Acad Sci U S A. 2012;109(3):770-4. https://doi.org/10.1073/pnas.1112173109.

40. Muhammad T, Govindu M, Srivastava S. Relationship between chewing tobacco, smoking, consuming alcohol and cognitive impairment among older adults in India: a cross-sectional study. BMC Geriatr. 2021;21(1):85. https://doi.org/10.1186/s12877-021-02027-x.

41. Osborne J, King JE. Binary logistic regression. In: Best Practices in Quantitative Methods: SAGE Publications, Inc.; 2011. p. 358-84.

42. StataCorp. Stata: Release 14. Statistical Software. College Station: StataCorp LP; 2015.

43. Sun X, Lucas H, Meng Q, Zhang Y. Associations between living arrangements and health-related quality of life of urban elderly people: a study from China. Qual Life Res. 2011;20(3):359-69. https://doi.org/10.1007/ s11136-010-9752-z.

44. Hays JC. Living arrangements and health status in later life: a review of recent literature. Public Health Nurs. 2002;19(2):136-51. https://doi.org/10.1 046/j.1525-1446.2002.00209.x.

45. Michael YL, Berkman LF, Colditz GA, Kawachi I. Living arrangements, socia integration, and change in functional health status. Am J Epidemiol. 2001; 153(2):123-31. https://doi.org/10.1093/aje/153.2.123.

46. Davis MA, Moritz DJ, Neuhaus JM, Barclay JD, Gee L. Living arrangements, changes in living arrangements, and survival among community dwelling 
older adults. Am J Public Health. 1997;87(3):371-7. https://doi.org/10.2105/A JPH.87.3.371.

47. Li LW, Zhang J, Liang J. Health among the oldest-old in China: which living arrangements make a difference? Soc Sci Med. 2009;68(2):220-7. https://doi. org/10.1016/j.socscimed.2008.10.013.

48. Zhang W, Liu G. Childlessness, psychological well-being, and life satisfaction among the elderly in China. J Cross Cult Gerontol. 2007;22(2):185-203. https://doi.org/10.1007/s10823-007-9037-3.

49. Henning-Smith C, Shippee T, Capistrant B. Later-life disability in environmental context: why living arrangements matter. Gerontologist. 2018;58(5):853-62. https://doi.org/10.1093/geront/gnx019.

50. Khazem LR. Physical disability and suicide: recent advancements in understanding and future directions for consideration. Curr Opin Psychol. 2018;22:18-22. https://doi.org/10.1016/j.copsyc.2017.07.018.

51. Henning-Smith C, Gonzales $\mathrm{G}$. The relationship between living alone and self-rated health varies by age: evidence from the National Health Interview Survey. J Appl Gerontol. 2020;39(9):971-80.

52. Chen $X$, Silverstein M. Intergenerational social support and the psychological well-being of older parents in China. Res Aging. 2000;22(1): 43-65. https://doi.org/10.1177/0164027500221003.

53. Sereny M. Living Arrangements of Older Adults in China : The Interplay Among Preferences, Realities, and Health; 2011.

54. Muhammad T, Srivastava S, Sekher TV. Association of self-perceived income status with psychological distress and subjective well-being: a crosssectional study among older adults in India. BMC Psychol. 2021;9(1):1-13.

55. Knodel J. Living arrangements of older persons around the. World. 2017; 32(2):373-5.

56. Ćwirlej-Sozańska A, Wiśniowska-Szurlej A, Wilmowska-Pietruszyńska A, Sozański B. Determinants of ADL and IADL disability in older adults in southeastern Poland. BMC Geriatr. 2019;19(1):1-13.

57. Beydoun MA, Popkin BM. The impact of socio-economic factors on functional status decline among community-dwelling older adults in China. Soc Sci Med. 2005;60(9):2045-57. https://doi.org/10.1016/.jsocscimed.2004.08. 063. Epub 2004 Nov 18. PMID: 15743653.

58. Wang D, Zheng J, Kurosawa M, Inaba Y, Kato N. Changes in activities of daily living (ADL) among elderly Chinese by marital status, living arrangement, and availability of healthcare over a 3-year period. Environ Health Prev Med. 2009;14(2):128-41. https://doi.org/10.1007/s12199-0080072-7.

59. Andrade FLJP. de, Lima JMR de, fidelis K do NM, Jerez-Roig J, Lima KC de. Cognitive impairment and associated factors among institutionalized elderly persons in Natal, Rio Grande do Norte, Brazil. Rev Bras Geriatr e Gerontol. 2017;20(2):186-96. https://doi.org/10.1590/1981-22562017020.160151.

60. Gamage MWK, Hewage C, Pathirana KD. Associated factors for cognition of physically independent elderly people living in residential care facilities for the aged in Sri Lanka 11 medical and health sciences 1117 public health and health services 17 psychology and cognitive sciences 1701 psych. BMC Psychiatry. 2019;19(1):1-12.

61. De-Silva R, Disanayaka S, De Zoysa N, Sanjeewanie N, Somaratne S, Foster J, et al. Improvement in behavioral symptoms in patients with moderate to servere Alzheimer's. Clin Interv Aging. 2008;3(2):211-25.

62. Maroof M, Ahmad A, Khalique N, Ansari MA, Shah MS, Eram U. Prevalence and determinants of cognitive impairment among rural elderly population of Aligarh. Natl J Community Med. 2016;7(3):189-92.

63. Muhammad T, Srivastava S, Sekher TV. Association of self-perceived income sufficiency with cognitive impairment among older adults: a populationbased study in India. BMC Psychiatry. 2021;21(1):1-14.

64. Zhou Z, Cai L, Zhuang M, Hong YA, Fang Y. A longitudinal analysis of the association between the living arrangements and psychological well-being of older Chinese adults: the role of income sources. BMC Geriatr. 2019;19(1): $1-9$.

65. Bongaarts J, Zimmer Z. Living arrangements of older adults in the developing world: an analysis of demographic and health survey household surveys. J Gerontol B Psychol Sci Soc Sci. 2002;57(3):S145-57.

66. Gupta I, Sankar D. Health of the elderly in India: a multivariate analysis. J Heal Popul Dev Ctries. 2003:1-11.

67. Chaudhuri A, Roy K. Gender differences in living arrangements among older persons in India. J Asian Afr Stud. 2009:44(3):259-77. https://doi.org/10.1177/ 0021909609102897.

\section{Publisher's Note}

Springer Nature remains neutral with regard to jurisdictional claims in published maps and institutional affiliations.

\section{Ready to submit your research? Choose BMC and benefit from:}

- fast, convenient online submission

- thorough peer review by experienced researchers in your field

- rapid publication on acceptance

- support for research data, including large and complex data types

- gold Open Access which fosters wider collaboration and increased citations

- maximum visibility for your research: over $100 \mathrm{M}$ website views per year

At BMC, research is always in progress.

Learn more biomedcentral.com/submissions 